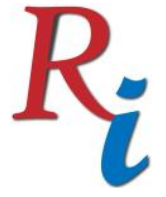

Asia Proceedings of Social Sciences

(APSS)

www.readersinsight.net/APSS

\title{
MULTI DIMENSIONALITY OF WORK FAMILY CONFLICT IN EAST AND WEST: HOW DO MALAYSIANS FARE?
}

Zaiton Hassan*

Departement Human Resource Development Program Universiti Malaysia Sarawak

Malaysia

\section{Nur Fatihah Abdullah Bandar}

Departement Human Resource Development Program

Universiti Malaysia Sarawak

Malaysia

\section{Surena Sabil}

Departement Human Resource Development Program

Universiti Malaysia Sarawak

Malaysia

\section{Dayang Kartini Abang Ibrahim}

Departement Human Resource Development Program

Universiti Malaysia Sarawak

Malaysia

\section{Nik Norsyamimi Md Nor}

Departement Human Resource Development Program

Universiti Malaysia Sarawak

Malaysia

*Corrosponding author's Email: hzaiton@unimas.my

Peer-review under responsibility of $3^{\text {rd }}$ Asia International Multidisciplanry Conference 2019 editorial board

(http://www.utm.my/asia/our-team/)

(C) 2019 Published by Readers Insight Publisher, lat 306 Savoy Residencia, Block 3 F11/1,44000 Islamabad. Pakistan,

info@readersinsight.net

This is an open access article under the CC BY-NC-ND license (http://creativecommons.org/licenses/by-nc-nd/4.0/). 


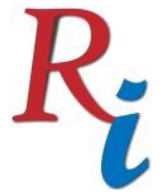

\section{Asia Proceedings of Social Sciences \\ (APSS) \\ www.readersinsight.net/APSS}

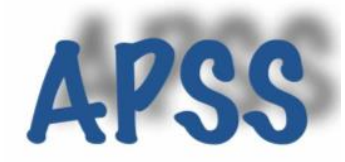

\section{Re search $\mathrm{H}$ igh I igh t s}

Malaysians employees significantly experienced less time and strain based WFC compared to Western employees. However, Malaysian employees experienced significantly more behavior-based WFC compared to Western counterparts. Malaysian employees in this study scored second lowest in time-based WFC and lowest in strain-based WFC. On the other hand, Malaysian employees experienced second highest behavior based WFC compared to Western employees. It is interesting to note that, in contrast to Western findings, the Malaysian employees experienced more behavior based conflict than time based or strain based conflict, particularly among male Malaysian employees. Cultural dimension such as collectivism and gender role ideology may explained the findings.

\section{Research Objectives}

The aim of this study is to advance the understanding of work-family conflict types, that is, time based, strain based and behavior based work-family conflict in Eastern culture by comparing it with eleven Western studies that utilized the same measure (work-family conflict scale by Carlson, Kacmar \& Williams, 2000). Although work family conflict was investigated heavily both in Eastern and Western context, not many studies examined the type or multidimensionality of work-family namely, time-based, strain-based and behavior based as espoused by the literature. By understanding the specific types of the work-family conflict (WFC), more specific interventions can be undertaken by organizations to minimize the work-family conflict experienced by their employees.

\section{Methodology}

Western studies were found by using database such as Science Direct and Business Source Complete. Keywords entered were "work-family conflict measure" and "Carlson". A total of five articles were found, and one article, Lapierre et al (2008) reported mean score of WFC for five countries. A total of eleven studies were utilised to compare with a Malaysian study. Nine studies represented the United States (Boyar \& Mosley Jr, 2007; Bruck, Allen, \& Spector, 2002; Carlson, Derr, \& Wadsworth, 2003; Carlson, Kacmar, \& Williams, 2000; Golden, Veiga, \& Simsek, 2006; Lapierre et al., 2008; Rotondo, Carlson, \& Kincaid, 2003; Shockley \& Allen, 2007; Witt \& Carlson, 2006), two from Australia and New Zealand (Herst, 2003; Lapierre et al., 2008), and one from Canada (Lapierre et al., 2008) and Finland (Lapierre et al., 2008). Only two (2) western studies reported types of WFC based on gender. For Malaysian study, 1000 self administered questionnaire were distributed to six public and private organizations in Kuching, Sarawak. Around 506 respondents responded.

\section{Results}

Data was analyzed using SPSS version 23 and presented using mean, standard deviation, internal reliability and one sample t-test result. Over half of the respondents were male $(56 \%)$. The majority were non-executives $(74 \%)$, had permanent posts $(82 \%)$, and were in the age group of 35 to 55 (63\%), were married for an average of 15 years (78\%) with 1 to 9 children $(74 \%)$, and had a working spouse $(50 \%)$. A total of $44 \%$ were Malay, $50 \%$ were Muslim, representing the Malaysian population. About $74 \%$ reporting religion as important in their life and $72 \%$ perceived themselves as religious. Around $32 \%$ had 11 years of education, with a $20 \%$ had a bachelor degree. 


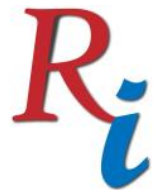

\section{Asia Proceedings of Social Sciences (APSS) \\ www.readersinsight.net/APSS}

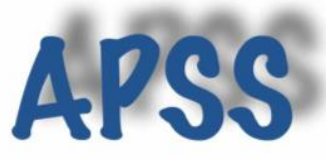

Most of the one sample $t$ test results comparing Malaysian mean scores and Western scores were significant. For time-based WFC, mean score for Malaysian employees is 2.72 and Western studies range between 2.90 to 3.55. For strain-based WFC, Malaysian respondents scored 2.68, while Western respondents scored between 2.09 to 3.29 With regard to behaviorbased WFC, Malaysian employees (both male and female) scored 2.68, while Western employees score range between 2.43 to 2.96 .

\section{Findings}

In general, Malaysians employees significantly experienced less time and strain based WFC compared to Western employees. However, Malaysian employees experienced significantly more behavior-based WFC compared to Western counterparts. Malaysian employees in this study scored second lowest in time-based WFC and lowest in strain-based WFC. On the other hand, Malaysian employees experienced second highest behavior based WFC compared to Western employees. It is interesting to note that, in contrast to Western findings, the Malaysian respondents experienced more behavior based conflict than time based or strain based conflict, particularly among male Malaysian employees. Cultural dimensions of Malaysians such collectivist and traditional gender role ideology may be the reasons for these findings.

\section{References}

Carlson, D. S., Kacmar, K. M., \& Williams, L. J. (2000). Construction and initial validation of a multidemensional measure of work-family conflict. Journal of Vocational Behavior, 56(2), 249-276.

Carlson, D. S., Derr, B. C., \& Wadsworth, L. L. (2003). The Effects of Internal Career Orientation on Multiple Dimensions of Work-Family Conflict Journal of Family and Economic Issues 24(1), 99-116.

Herst, D. E. L. (2003). Cross-cultural measurement invariance of work/family conflict scale across English-speaking samples. University of South Florida

Lapierre, L. M., Spector, P. E., Allen, T. D., Poelmans, S., Cooper, C. L., O'Driscoll, M. P., \& Kinnunen, U. (2008). Family-supportive organization perceptions, multiple dimensions of work-family conflict, and employee satisfaction: A test of model across five samples. Journal of Vocational Behavior, 73(1), 92-106.

Rotondo, D. M., Carlson, D. S., \& Kincaid, J. F. (2003). Coping with multiple dimensions of workfamily conflict. Personnel Review, 32(3), 275. 